\title{
Pharmaceutical Services in Primary Health Care: are pharmacists and users on the same page?
}

\author{
Serviços farmacêuticos na Atenção Básica: \\ há sintonia entre farmacêuticos e usuários?
}

\author{
Tatiana Chama Borges Luz ${ }^{1}$ \\ Maria Emília Silva de Souza Costa ${ }^{1}$ \\ Daniela Santana Portes ${ }^{1}$ \\ Lucas Barbi Costa e Santos ${ }^{1}$ \\ Samuel Rodrigues Almeida e Sousa ${ }^{1}$ \\ Vera Lucia Luiza ${ }^{2}$
}

${ }^{1}$ Instituto René Rachou, Fiocruz. Av. Augusto de Lima 1715/Anexo, Barro Preto. 30190-002 Belo Horizonte MG Brasil.tatianachama@ cpqrr.fiocruz.br ${ }^{2}$ Escola Nacional de Saúde Pública, Fiocruz. Rio de Janeiro RJ Brasil.

\begin{abstract}
This study investigated structural and organizational characteristics of the Pharmaceutical Services based on Primary Health Care (PHCPS) from the viewpoints of users and pharmacists. A mixed method design was applied, combining one-to-one semi-structured interviews with four pharmacists in charge of five public dispensing facilities and 69 users, with a secondary database analysis. Data were collected from February to August 2014 in Divinópolis, a municipality in Minas Gerais State. PHCPS were similar in terms of general activities performed and staff profile and background. While users were concerned about medicines' availability and improvements related to the PHCPS' conveniences and personnel, pharmacists pointed out problems regarding infrastructure to storage. Despite most users had low information on how to use their medicines, no pharmacists declared to participate in medicines dispensing activities. There was a low match between users and pharmacists viewpoints and advantages for concentrate medicines dispensing in a smaller number of facilities were not clear.
\end{abstract}

Key words Primary Health Care, Pharmaceutical services, Pharmacists, Outpatients
Resumo Este estudo investigou características estruturais e organizacionais de serviços farmacêuticos na Atenção Primária à Saúde, a partir do ponto de vista de farmacêuticos e de usuários. Foi utilizado delineamento de métodos mistos, combinando entrevistas semiestruturadas com 69 usuários e 4 farmacêuticos responsáveis pelos 5 serviços que dispensam medicamentos para a população, com análise de dados provenientes de banco de dados municipal. Coletaram-se os dados de fevereiro a agosto de 2014, em Divinópolis, município de Minas Gerais. Os serviços foram similares em termos das atividades realizadas e do perfil profissional dos trabalhadores. Enquanto os usuários preocupavam-se com a disponibilidade de medicamentos e desejavam a melhoria da estrutura dos serviços e dos recursos humanos, os farmacêuticos apontaram problemas relativos ao armazenamento dos medicamentos. Apesar da maioria dos usuários relatarem poucas informações sobre a utilização de seus medicamentos, nenhum farmacêutico declarou participar de atividades de dispensação. Houve pouca concordância entre os pontos de vistas de usuários e de farmacêuticos. A vantagem de se concentrar a dispensação de medicamentos em um número reduzido de unidades dispensadoras não foi observada na prática.

Palavras-chave Atenção Primária à Saúde, Serviços farmacêuticos, Farmacêuticos, Usuários 


\section{Introduction}

Pharmaceutical Services based on Primary Health Care (PHCPS) aim to contribute to comprehensive, integrated and continuous care for addressing medicine-related health needs and problems of the population, both individual and collective ${ }^{1}$.

As an essential component in healthcare organizations, the PHCPS, more than allowing steady pharmacological treatments, can contribute to decrease treatments' cost, thanks to primary interventions and preventing patient forwarding to further medical care. Besides, it is a suited place to obtain information, offering adequate conditions for conducting health and social educational activities ${ }^{1,2}$.

In Brazil, over the past 18 years the Ministry of Health has published a series of policy documents and guidelines setting out how the PHCPS should be designed in order to offer the conditions for dispensing medicines to the population and to provide a humanized care ${ }^{3-7}$. However, weaknesses in the structuring of the services still persist $^{8}$. Several authors have shown problems at PHCPS, such as low availability of medicines ${ }^{9-11}$, inattention to the legal rules for medicines procurement $^{12}$; inadequacies in the dispensing area $^{9,13}$, in medicines storage $e^{9,12,13}$ and in inventory control ${ }^{12}$. Additionally, there is a large number of patients who do not have satisfactory knowledge about their prescribed treatment ${ }^{13,14}$.

This study investigated structural and organizational characteristics of the PHCPS as well as alternatives to improve them, from the viewpoints of the users and pharmacists, in order to better understand the full suite of services that are being offered to the community.

\section{Methods}

\section{Design and setting}

This study employed a mixed method de$\operatorname{sign}^{15}$ and is part of the "Servir Project", a qualitative investigation carried on in Divinópolis, a municipality of approximately 200,000 inhabitants in the State of Minas Gerais, in southeastern Brazil, from February to August 2014. Divinópolis is the health pole city for 56 other municipalities from the State Western macro region. A pole city is supposed to be a reference in secondary and tertiary care, and be easily accessible to the polarized cities ${ }^{16}$. The city is divided in Health
Districts, five of which have healthcare units with PHCPS responsible for providing prescription medicines to the population covered by the adjoined area.

\section{Data collection and instruments}

All the PHCPS were included in the study. A series of one-to-one, semi-structured audio-recorded interviews were undertaken by trained interviewers, with each chief pharmacist and also PHCPS' users. Chief pharmacists were selected since they are directly responsible for the managerial choices within these services. Professionals were interviewed at the workplace, while users were interviewed right after dispensing. Eligible users were individuals aged 18 years or over, receiving medicines dispensed by the pharmacy for at least 6 months prior to the interview and that agreed to participate in the study. For users, purposeful sampling technique was employed. This technique is widely used in qualitative research for the identification and selection of information-rich cases that are able to communicate experiences and opinions in an articulate, expressive, and reflective manner ${ }^{17,18}$. PHCPS' users were recruited until data saturation was reached and no new themes emerged from the interviews ${ }^{17}$.

Specific interview guides for pharmacists and users were developed based on the a Brazilian guideline on Pharmaceutical Services ${ }^{5}$, and also contained questions developed by the research team and other questions adapted from the literature $^{19-22}$. These instruments were designed to explore multiple view points of the participants regarding the PCHPS and to enable triangulation of results. Pharmacists and patients were interviewed about dispensing area (space, comfort and waiting time and queues), obtainment of prescribed medicines and general opinion about the service (how they evaluated the service and whether they would like to change anything about it and what kind of changes might be desirable). Pharmacists gave information on PCHPS' organization and management (main activities developed by the pharmacy, number of pharmacists and their role in dispensing practices, number and background of dispensary assistants, existence of computerized dispensing registration system, availability of informative material to users). Patients, on the other hand, were asked about aspects of their interaction with the pharmacy staff (previous contact with the pharmacist - if not, why - and whether information 
about the dispensed medicine and its potential adverse reaction were provided). Additionally, users were asked to show the prescription to the interviewer in order to check how many different medicines were prescribed in the last medical visit. They were also questioned about continuous use of medicines and how they were supposed to take their medicines. Demographic information was recorded for each participant at the time of the interview.

The Municipal Health Secretariat (SEMUSA) provided supplementary data on the total number of users assisted at the PHCPS. Data were abstracted from the database "Sistema Integrado de Saúde" (SIS), being collected for a six month period, from January to June, 2014.

\section{Data analysis}

The analysis presented here is a multi-step procedure where the analytical categories were defined a posteriori. Thematic content analysis of the interviews was carried out by the research team via an iterative process ${ }^{17,23}$. Transcripts were initially read and notes were taken regarding key themes and issues. In sequence, transcripts were independently and thoroughly re-read and categories were freely generated. Relevant data segments were copied from transcripts into Microsoft Excel spreadsheets and a series of group analysis sessions was conducted to develop the final coding frame. Concepts and definitions used in this coding frame were based on three guidelines: (1) the Brazilian guideline on Pharmaceutical Services ${ }^{5}$; (2) Starfield ${ }^{24}$ and (3) WHO-MSH ${ }^{25}$. Each final category or topic was organized into larger themes and subthemes following the coding frame and then this coding frame was applied to all data.

Part of the qualitative data was then quantitized, i.e., numerical or ordinal values were assigned to those data, and a database was prepared using the software package SPSS 22.0 for Windows (IBM Corporation, USA). This procedure was adopted in order to add clarification, facilitate pattern recognition and extract meaning from data ${ }^{26}$. The variables generated by this process were grouped as "viewpoints" and organized in the domains "infrastructure and service organization" of the PHCPS and "dispensing practices and medicine availability". Following the final coding frame, answers to questions related to the provision of information on medicines (e.g., regarding medicines' name and indication, instructions on how to take them and description of adverse reactions) were dicotomically computed as "yes" if the respondent could give details on these information, otherwise, they were computed as "no". The same rationale was used to assign values to the variable "users knowledge about the daily dosage", which means that "knowledge" was considered positive only if the user explained the daily dose frequency and how he or she took it. Descriptive statistics were used to analyze these data (means and standard deviations, frequencies, and proportions).

Data on the service delivery currently provided was obtained from pharmacists as his or her general opinion about these services (how do you rate service delivery provided to patients here at this PHCPS: excellent, good, reasonable, poor, very poor). Both pharmacists and PHCPS' users were questioned (open-ended) about aspects to improve in the service delivery (would you like to change anything about this PHCPS? What kind of changes would be desirable in your opinion?). After applying the categorization strategy presented above, these data were grouped in the domain "Service Delivery Improvements".

In order to estimate the average dispensing time, we computed two indicators: (1) the average number of users assisted per day and per dispensary assistant (AUD) and (2) the average dispensing time (ADT). These indicators were computed for each PHCPS using the average number of users assisted per month, provided by the SIS database, combined with information provided by the PHCPS' pharmacists regarding the number of dispensary assistants working at the PHCPS, and the daily number of hours dedicated to dispensing activities ( 5 hours or 300 min). We considered 22 working days per month for the PHCPS in order to estimate the average number of users assisted per day. These indicators were computed using the using the following formulas:

a) $\mathrm{AUD}=\frac{\text { average number of users assisted per day }}{\text { number of dispensary assistants }}$
b) $\mathrm{ADT}=\frac{\text { minutes of dispensing per day }(300 \mathrm{dmin})}{\mathrm{AUD}}$

Ethics

Ethical approval for the study was obtained from René Rachou Research Center' Ethics Committee (Reference: 377.134). All participants signed the informed consent. Anonymity and confidentiality were assured and any identifying 
features, such as participant name or location were removed to avoid participants being identified. Information that could allow identifying the PHCPS investigated were aggregated.

\section{Results}

A total of seventy three interviews from the five different PHCPS were conducted (4 interviews with the PHCPS' chief pharmacists and 69 with PHCPS' users). Among pharmacists, there were no refusals to participation in this investigation. At the time of the study, one pharmacist was responsible for two different PHCPS. The mean age of these professionals was 33.8 years [ $\mathrm{SD}=$ \pm 7.6 . The majority of them had less than five years on-the-job experience.

According to pharmacists, the main activities developed by the PHCPS were supply management, which include medicines' programming, storage and inventory, and dispensing to users. Most of the PCHPS had only one pharmacist - except for PHCPS 3 and 4, that had two pharmacists each - and none of the interviewees stated involvement in dispensing activities. The number of dispensary assistants working at the PCHPS totalled 26, ranging across units from 3 to 9 (data per PHCPS not shown to prevent identification). The dispensary assistants' main background was nursing technicians or nursing auxiliaries. All services counted with computerized system to register dispensing activities, but there was no informative material to be delivered to users.

The mean number of users assisted per PHCPS per month was 4,405 individuals [SD $= \pm 2,458 ; \min =2,599 ; \max =8,628]$. The average number of users assisted per day and per dispensary assistant at the PHCPS (AUD) was 39 individuals $[\min =32 ; \max =44]$ and the average dispensing time was $7.6 \mathrm{~min}[\mathrm{~min}=6.9 ; \max =$ $9.5 \mathrm{~min}]$ (ADT).

Table 2 illustrates the basic characteristics of the PHCPS' users. The predominant characteristics were: female gender, married, with less than 7 years of schooling and monthly personal income bellow two Brazilian minimum wages. Most of the participants reported continuous use of medicines, with the average number of medicines taken varying from 2.9 to 4.3 products.

Data analysis generated three domains from PHCPS' pharmacists and users viewpoints that are described below.

\section{A) Infrastructure and Service Organization}

Viewpoints of users and pharmacists regarding PHCPS' infrastructure and service organization varied and were mostly discordant (Tables 1 to 3). Regarding physical space, for instance, in two services - PHCPS 1 and 5, pharmacists were more severe than the users themselves. The same occurred for comfort-PHCPS 5, and waiting time - PHCPS 4 and 5. On the other hand, at PHCPS 3 while the pharmacist considered space, comfort and waiting time adequate, users strongly disagree with the professional. PHCPS 2' pharmacist and users also diverged, but only on waiting time.

\section{B) Dispensing practices and medicine availability}

The majority of PHCPS' users had never had contact with their pharmacist. When asked for reasons for having never sought this professional, most of the users replied that they had never needed a pharmacist (Table 3).

In spite of not being directly involved in dispensing activities, all pharmacists pointed out that users usually demand information on dispensed medicines or treatment, however, when the users were questioned, right after dispensing, whether they received information on their medicines' names, indication, adverse reactions or even on how to take them, the majority were unable to repeat any of these information (Table 3). Particularly, users from the PHCPS 1 and 5 had greater difficulty in reporting how they should take their prescribed medicines.

Only about half or less of the users were able to obtain all their medicines, but even those who could have their prescription filled, had problems to get them in the right quantities. In general, pharmacists agree that the users are not receiving their medicines at the PHCPS, except the professionals at the PHCPS 2 and 3 (Table 1).

\section{C) Service delivery improvements}

The major themes regarding aspects to improve in the service delivery yielded during thematic analysis are presented in Table 4 . In order to preserve anonymity, pharmacists speeches are presented here as "chief pharmacist A/B/C or D". There is no correspondence between these letters and the PHCPS.

From PHCPS' users opinions, seven main themes emerged. Three of these were similar for all five PHCPS: "medicines' availability"; “in- 
Table 1. Pharmacists viewpoints on PHCPS. Servir Project, Divinópolis, Minas Gerais, Brazil, 2014.

\begin{tabular}{|c|c|c|c|c|c|}
\hline Characteristic & PHCPS(1) & PHCPS(2) & PHCPS(3) & PHCPS(4) & PHCPS(5) \\
\hline Physical space for users & Inadequate & Inadequate & Adequate & Adequate & Inadequate \\
\hline Comfort for users & Uncomfortable & Uncomfortable & Comfortable & Comfortable & Uncomfortable \\
\hline Waiting time & Long & Adequate & Adequate & Reasonable & Reasonable \\
\hline $\begin{array}{l}\text { Users are able to obtain } \\
\text { all needed medicines }\end{array}$ & No & Partially & Yes & No & No \\
\hline $\begin{array}{l}\text { Service delivery } \\
\text { evaluation }\end{array}$ & Good & Very good & Good & Good & Very good \\
\hline
\end{tabular}

PHCPS: Pharmaceutical Services based on Primary Health Care.

Table 2. Demographic/background characteristics of PHCPS’ users. Servir Project, Divinópolis, Minas Gerais, Brazil, 2014.

\begin{tabular}{|c|c|c|c|c|c|}
\hline Characteristic & $\begin{array}{c}\operatorname{PHCPS}(1) \\
\mathrm{n}=14\end{array}$ & $\begin{array}{c}\text { PHCPS(2) } \\
n=13\end{array}$ & $\begin{array}{c}\operatorname{PHCPS}(3) \\
\mathrm{n}=14\end{array}$ & $\begin{array}{c}\text { PHCPS(4) } \\
n=15\end{array}$ & $\begin{array}{c}\text { PHCPS (5) } \\
n=13\end{array}$ \\
\hline Female gender (\%) & 78.6 & 53.8 & 78.6 & 50.0 & 50.0 \\
\hline Age, mean (SD) & $53.3(14.9)$ & $51.0(14.2)$ & $48.4(15.0)$ & $59.3(9.2)$ & $56(9.6)$ \\
\hline Married $^{(\mathrm{a})}(\%)$ & 64.3 & 69.2 & 50.0 & 71.4 & 58.3 \\
\hline Schooling $\leq 7$ years $(\%)$ & 78.6 & 61.6 & 64.3 & 46.7 & 66.7 \\
\hline Monthly personal income $<2^{(\mathrm{b})}(\%)$ & 57.1 & 92.3 & 64.3 & 53.3 & 50.0 \\
\hline Continuous use of medicines (\%) & 92.9 & 81.8 & 100.0 & 93.3 & 91.7 \\
\hline $\begin{array}{l}\text { Average number of medicines taken, } \\
\text { number (SD) }\end{array}$ & $4.3(2.7)$ & $4.2(2.3)$ & $3.7(1.7)$ & $2.9(1.6)$ & $3.3(1.4)$ \\
\hline
\end{tabular}

frastructure" and "services organization". Two themes appeared in four services ("acceptability" and "human resources"), while other two - "counselling and monitoring" and "geographic accessibility" - were raised in two services. Themes emerged from pharmacists were: "infrastructure" $(4 / 5)$; "service organization" (1/5); "human resources" (1/5) and" medicines' selection" (1/5) “.

Users from PHCPS 3 and 4 were the most critical, proposing changes for the existing services that belong to the seven emerged themes, while users from PHCPS 5 only mentioned improvements from three themes (Table 4). Pharmacists, in general, were short and concise when invited to think about aspects to be improved in the PHCPS. Indeed, pharmacist from PHCPS 3, contrary to users, preferred not to comment or give suggestions.

One of the main recurrent issues was the "availability of medicines". Users from all the services investigated unanimously requested their medicines at their disposal when they need:

This medicine I need is always out of stock. Last month I came here and it was out of stock. Now
again...You know, I need to take this! What can I do now? I'll need to find a way. I have to. I can't remain without taking it, right? [PHCPS' user 1]

Most pharmacists recognized that the users are not being able to obtain their medicines at the PHCPS (Table 1). Despite of that, this did not seem to be a concern to them, since no professional mentioned improvements regarding availability. In fact, what one professional mentioned was the need of reviewing the essential medicines list, i.e., those medicines that satisfy the priority health care needs of the population ${ }^{27}$.

In my opinion they should review the medicines list, because today there is this increasing demand for medicines that are not included at the Municipal Essential Medicines List, so the users end up going to the Court. This litigation aggravates problems in Pharmaceutical Services management, so one possibility is to include these medicines in the list to reduce the costs to the healthcare system. [Chief Pharmacist A]

Another general agreement among users was that PHCPS' infrastructure needed some upgrade in terms of physical space, seats in the 
Table 3. Users viewpoints on PHCPS' infrastructure, service organization, dispensing practices and medicines availability. Servir Project, Divinópolis, Minas Gerais, Brazil, 2014.

\begin{tabular}{|c|c|c|c|c|c|}
\hline \multirow{3}{*}{ Characteristic } & \multicolumn{5}{|c|}{ Users Viewpoints (\%) } \\
\hline & PHCPS(1) & PHCPS(2) & PHCPS(3) & PHCPS(4) & PHCPS(5) \\
\hline & \multicolumn{5}{|c|}{ Infrastructure and service organization } \\
\hline \multicolumn{6}{|l|}{ Physical Space } \\
\hline Adequate & 61.5 & 23.1 & 0.0 & 77.8 & 91.7 \\
\hline Reasonable & 15.4 & 7.7 & 7.1 & 22.2 & 0.0 \\
\hline Inadequate & 23.1 & 69.2 & 92.9 & 0.0 & 8.3 \\
\hline \multicolumn{6}{|l|}{ Comfort } \\
\hline Comfortable & 35.7 & 15.4 & 7.1 & 73.3 & 63.6 \\
\hline Reasonable & 28.6 & 7.7 & 21.4 & 20.0 & 0.0 \\
\hline Uncomfortable & 35.7 & 76.9 & 71.4 & 6.7 & 36.4 \\
\hline \multicolumn{6}{|l|}{ Waiting time } \\
\hline Adequate & 40.0 & 16.7 & 7.1 & 53.3 & 70.0 \\
\hline Reasonable & 0.0 & 33.3 & 7.1 & 20.0 & 10.0 \\
\hline \multirow[t]{2}{*}{ Too long / long } & 60.0 & 50.0 & 85.7 & 26.7 & 20.0 \\
\hline & \multicolumn{5}{|c|}{ Dispensing practices and medicines availability } \\
\hline \multicolumn{6}{|l|}{ Previous contact with the Pharmacist } \\
\hline Yes & 0.0 & 0.0 & 0.0 & 6.7 & 7.7 \\
\hline No & 100.0 & 100.0 & 100.0 & 93.3 & 92.3 \\
\hline \multicolumn{6}{|l|}{ Given reasons for not contacting the pharmacist } \\
\hline $\begin{array}{l}\text { Did not know that there was an available } \\
\text { pharmacist }\end{array}$ & 0.0 & 22.2 & 36.4 & 30.8 & 0.0 \\
\hline Never needed a pharmacist & 100.0 & 77.7 & 63.6 & 69.2 & 100.0 \\
\hline \multicolumn{6}{|c|}{ Information on medicines' names and indications were provided } \\
\hline Yes & 0.0 & 0.0 & 15.4 & 0.0 & 7.7 \\
\hline No & 100.0 & 100.0 & 84.6 & 100.0 & 92.3 \\
\hline \multicolumn{6}{|c|}{ Instructions on how to take medicines were provided } \\
\hline Yes & 0.0 & 30.8 & 15.4 & 6.7 & 45.5 \\
\hline No & 100.0 & 69.2 & 84.6 & 93.3 & 54.5 \\
\hline \multicolumn{6}{|c|}{ Instructions on adverse reactions or potential problems with medicines were provided } \\
\hline Yes & 0.0 & 0.0 & 0.0 & 14.3 & 7.7 \\
\hline No & 100.0 & 100.0 & 100.0 & 85.7 & 92.3 \\
\hline \multicolumn{6}{|l|}{ Knowledge about the daily dosage } \\
\hline Yes & 21.4 & 84.6 & 92.9 & 86.7 & 30.8 \\
\hline No & 78.6 & 15.4 & 7.1 & 13.3 & 69.2 \\
\hline \multicolumn{6}{|l|}{ Able to obtain all prescribed medicines } \\
\hline Yes & 57.1 & 46.2 & 35.7 & 33.3 & 57.1 \\
\hline No & 42.9 & 53.8 & 64.3 & 66.7 & 42.9 \\
\hline \multicolumn{6}{|c|}{ Able to obtain all dispensed medicines in the appropriate quantity } \\
\hline Yes & 69.2 & 58.3 & 57.1 & 73.3 & 100.0 \\
\hline No & 30.8 & 41.7 & 42.9 & 26.7 & 0.0 \\
\hline
\end{tabular}

PHCPS: Pharmaceutical Services based on Primary Health Care.

waiting area, water dispenser and cups to drink, bathroom, fan or air conditioning and shelter from rain and sun in the waiting area:

I think they need to find a way to accommodate more people. It is so tight there! Have you seen the dust? I even thought about bringing these issues to one of the city council members. If they could change it, I'd be so much happy... But I don't like to bother anyone, I'm being very well treated by people here, so let it be. But we see problems every day. When the rain comes, the walls need to be painted... And the benches are so uncomfort- 
Table 4. Aspects to improve in the PHCPS' service delivery according to users and pharmacists' views. Servir Project, Divinópolis, Minas Gerais, Brazil, 2014.

\begin{tabular}{llllll}
\hline \multirow{2}{*}{ Participant } & \multicolumn{5}{c}{ Main Themes } \\
\cline { 2 - 6 } Users & \multicolumn{1}{c}{ PHCPS(1) } & \multicolumn{1}{c}{ PHCPS(2) } & \multicolumn{1}{c}{ PHCPS(3) } & \multicolumn{1}{c}{ PHCPS(4) } & PHCPS(5) \\
\cline { 2 - 6 } & Acceptability & Acceptability & Acceptability & Acceptability & Infrastructure \\
& Infrastructure & Infrastructure & Counseling and & Counseling and & Medicines' \\
& Medicines' & Medicines' & monitoring & monitoring & availability \\
& availability & availability & Geographic & Geographic & Service \\
& Human & Human & accessibility & accessibility & organization \\
& Resources & Resources & Human Resources & Human Resources & \\
& Service & Service & Infrastructure & Infrastructure & \\
& organization & organization & Medicines' & Medicines' & \\
& & & availability & availability & \\
& & & Service organization & Service organization & \\
Pharmacists & Service & Infrastructure & & Infrastructure & Infrastructure \\
& organization & & Medicines' selection & \\
& Infrastructure & & & & \\
& Human & & & & \\
& Resources & & & & \\
\end{tabular}

PHCPS: Pharmaceutical Services based on Primary Health Care. ${ }^{(a)}$ Pharmacist responsible for the PHCPS 3 could not think of aspects to be improved.

able! The Mayor spends so much money in other things... this would be nothing for him but great for the community! [PHCPS' user 34]

Some users also suggested that bags could be provided to transport their medicines:

They could, at least, offer us a small bag to carry the medicines. Sometimes we forget to bring it from home and we need to go back with our medicines in our own hands. [PHCPS' user 59]

Pharmacists also commented about the need of improvements regarding PHCPS' infrastructure, but mainly regarding storage area and the need of equipments and furniture:

We need computers. Our refrigerator is too small. We need to change the medicine's cabinet, we can't close the doors. There is no place for proper storage. Our space is not good. We should move to another place, this pharmacy is too small! [Chief Pharmacist A]

Unfortunately our storage area is not big enough to meet a five-fold increase in the demand. [Chief Pharmacist D]

PHCPS' users complained about service organization, asking for a more orderly service, with shorter queues, that adopt a marker system and that prioritize seniors, people with small children and people with disabilities.

It is too crowded and noisy here! [PHCPS' user 49]

There are sick people here moaning, I don't speak in my behalf, I can wait, but I don't think they can, they are suffering! Sometimes we need to wait here for two hours! It is too much! Some people yell, others faint. It is just wrong... And, of course, the seniors... They should attend them first! [PHCPS' user 19]

I wish they used tickets so everyone could get in here and take his or her ticket and could seat while wait for the dispenser. [PHCPS' user 37]

Although only a few participants referred the need of more staff and agreed that some dispensary assistants did not treat PHCPS' users with sufficient respect, these opinions were echoed by interviewees from four in five of the services investigated, revealing the existence of problems regarding acceptability and human resources:

I think they should hire more people. It is not enough when there is just one person to pick up the medicines and register everything in the computer. [PHCPS' user 4]

I wish they treat me with respect. They should be more attentive to us, but only a few of them truly are. [PHCPS' user 54]

Along with the claim for a more personalized care, a few of users also recognized the importance of counselling and monitoring:

I wish a more humanized care, where people know each other and treat each other by their names, you know, I wish we had a better relationship. And regarding the medicines, I wish people here were more attentive. They don't say anything, they just give you your medicines and that is it! [PHCPS' user 30]

Pharmacists, in turn, also pointed out the need of more staff, but the issue related to the interpersonal aspects of the dispensers-users rela- 
tionship was not expressed, neither those related to counselling and monitoring.

It is not possible to work with an ever growing demand. Either they open more pharmacies or hire more people, because there will soon come a point where it will be impossible to work! [Chief Pharmacist C]

One pharmacist, however, commented about the need of more qualified staff to dispense medicines:

I think to be able to work at the pharmacy they should require qualification, got it? I mean, for you to be able to work at the pharmacy, you need to be a pharmacist or a pharmacy technician, but none of our PHCPS have pharmacy technicians, they don't hire pharmacy technicians here... [Chief Pharmacist A]

Some users believed that the expansion of the PHCPS in the municipality could improve geographic accessibility to the users:

My doctor sees me in another facility, but when he prescribes me medicines, I need to come here to get them. I think I should obtain my medicines there, not here! Why do they make me keep coming here? Why do they concentrate all the users in here, in this pharmacy? I think they should have pharmacies within every health care facility! [PHCPS' user 43]

\section{Discussion}

The findings revealed that, even though the PHCPS were relatively similar in terms of main activities developed, in the number of pharmacists, background of the dispensary assistants and use of computerized system to dispense medicines, the users and pharmacists' viewpoints varied across services.

Some users, for instance, outlined the discomfort with the physical spaces, the shortage of staff, the long queues and the waiting times. Despite the lack of other similar studies to allow direct comparison of these findings, our results are in accordance to other authors, that showed that the higher the waiting time (actual or perceived), the lower the level of the users' satisfaction $^{28-31}$. Problems regarding dispensary space are not uncommon in Brazil, as highlighted by other authors ${ }^{32,33}$ and one important recommendation for good pharmaceutical services is that dispensary space needs to be optimally designed to ensure efficient processing of prescriptions ${ }^{34}$. Therefore, any inconvenience regarding PHCPS' infrastructure and service organization can jeop- ardize the opportunity for individuals to receive proper care at these services ${ }^{35,36}$.

One particular aspect that users and pharmacists agreed on was the poor medicine availability at the PHCPS. According to information provided by the Divinopolis' Municipal Secretariat of Health, at the time of our data collection, the municipality was on a destocking period. This information can be corroborated by an official report from the Minas Gerais Court of Auditors that concluded that all the pharmaceutical services at the State were in high risk of destocking due to poor management practices ${ }^{37}$. Despite the importance of all dimensions of access to medicines, availability showed the strongest association with users satisfaction ${ }^{30,38}$.

In this study we also evaluated the PHCPS' dispensing practices, since dispensing medicines is one of the core activities of these services 5 . During dispensing, the users should be guided about the use of their medicines, the importance of follow the dosage directions and information on the influence of food and beverage, interaction with other medicines and potential adverse reactions, as well as the necessary storage conditions ${ }^{1}$. All these information are relevant not only to the appropriate use of medicines, but also, to improve treatment adherence ${ }^{39}$. Our results showed that, in general, PHCPS' users, based on what they had been told by the dispenser, were not able to report, right after dispensing, information on their medicines' names, indications, on how to take them and on possible adverse reactions. Besides, they also had difficulties in narrating the way they use their medicines at home. These findings also indicate that the quality of the dispensing practices at the PHCPS can be considered suboptimal and are in line with other authors ${ }^{12,40}$.

It should be mentioned that the pharmacists, as they stated themselves, did not involve in dispensing activities, a result already evidenced by other authors ${ }^{40-44}$. In fact, the dispensary assistants were the professionals identified as responsible for performing these tasks. However, we did not investigate their viewpoints on dispensing practices, since this was out of the scope of the Servir Project. Alternatively, we evaluated whether the suboptimal counselling was related to lack of time. We found that 39 was the mean number of individuals assisted by dispenser per day $[\min =32 ; \max =44]$ and $7.6 \mathrm{~min}$ was the average dispensing time $[\min =6.9 ; \max =9.5 \mathrm{~min}]$. Authors studying the average dispensing time in several settings in Brazil and worldwide have found figures varying from less than one minute 
to almost 9 minutes ${ }^{27,45-48}$. Nevertheless, WHO recommends at least 3 minutes for the orientation of each patient ${ }^{49}$, less than half the estimated time in our study. It is possible, however, that the dispensary assistants are not dedicating the entire estimated time to counselling activities, but also dedicating to administrative procedures. It is also possible that the staff does not have the necessary training or knowledge on directions of use, advice on side effects, precautions and other necessary information to users manage their treatment satisfactorily, or that there is a lack of communication skills ${ }^{48}$.

Another key finding from this study was that users and pharmacists' viewpoints regarding the improvement of the PHCPS strongly differ. On one hand, users wanted improvements related to the waiting area, such as more comfortable and acclimatized spaces, with seats, and accessible water and bathrooms. At the same time, they expressed a preference for prompt services that provide their needed medicines. On the other hand, pharmacists were more concerned with aspects related to the improvement of the conditions for storing medicines, such as readjustments of the storage space and renovation of furniture and equipments.

Overall, our results indicated that the pharmacist-user relationship was very tenuous and that the pharmacists clearly seemed to be too product-oriented, despite the growing role of these professionals in measuring, monitoring, and managing medicines use in healthcare systems worldwide ${ }^{50}$. Besides, even admitting that the PHCPS investigated were relatively large, serving around 2,500 to 8,600 users per month with limited staff and each service usually covering a wide geographic area, the same users visit the same PHCPS every one or two months. In other words, there is a realistic possibility of interaction and communication between the pharmacist and users that can truly benefit the latter. It is worth mentioning that users suggested having one dispensing facility by healthcare facility. Even considering that there are different dispensing organizations in the country, generally, the reason to concentrate services is to also concentrate the best service infrastructure and trained professionals ${ }^{51}$ what did not seem to be the case.

Pharmacists behaviours and attitudes within these services can be explained either by a professional preference for management activities due to possible failures in the pharmacists' training which is not focused on patients' care training and clinical issues ${ }^{43,45}$ or by the theory of organ- izational resilience, defined as the ability of an organization or its members to maintain their work in the face of an environment that is characterized by multiple goals, hazards and discontinuities in care $^{52}$. In this kind of environment, professionals adapt their work activities, creating a divergence between 'work as imagined' versus 'work as done'. The first corresponds to the formal and idealized activities and procedures to follow and the second to the actual practice ${ }^{53}$.

According to the Ministry of Health's guideline $e^{54}$, pharmaceutical services would have the purpose of promoting the rational use of the medicines in an integrated, continuous, safe and effective way for the individual, constituting, therefore, points of attention. Our findings, highlighting important weaknesses in the PHCPS of a polo municipality, indicate major challenges involved in transforming this reality in the country.

This study has some caveats. In qualitative studies, data are usually collected from a few cases or individuals ${ }^{17,18}$, so our findings do not represent the totality of PHCPS' users characteristics and viewpoints. Additionally, our results cannot be generalized to a larger population, since probability statistics were not applied to calculate sample sizes ${ }^{17,18}$. However, we investigated all PHCPS at a pole municipality, including each chief pharmacist, and a purposeful sample of the users, whose characteristics were, in general, similar to those users of public primary care in Brazil $^{55}$. Therefore, we believe that the results can be transferable to other similar contexts.

Data collection in qualitative studies is strongly influenced by the researcher's personal singularities and dependent on the individual skills. To improve rigor of data collection and minimize this bias, we conducted a standardized training of data collectors that were oriented not only to examine what respondents said but also to consider how they structured their responses ${ }^{17}$. These interviewers were not involved in dispensing or health care in the studied facilities and they had not previous relationship with the interviewees. We also adopted a methodological approach that improved data interpretation by employing a mixed method design and a multi-step procedure of data analysis to enhance study quality ${ }^{15}$.

Our results ratified previous studies that showed severe inefficiencies regarding the PHCPS. However, our methodological approach allowed us to go further, uncovering and describing viewpoints, experiences and aspects to be improved from both, providers - the pharmacists - and users of these services. In summary, 
while users have understandably focused on dispensing-related aspects, since these are more visible to them, pharmacists have addressed more managerial aspects of the services. Importantly, the results suggest that PHCPS' pharmacists do not embrace their role as primary care providers. It seems that the efforts of the Brazilian Govern- ment to promote pharmaceutical care practices in the country ${ }^{3}$ have not yet reached all pharmacists to effectively change their behaviour regarding supplying and dispensing medicines adequately. A more coordinated effort of the three federative levels in this direction is needed in order to achieve better results.

\section{Collaborations}

Luz was responsible for funding acquisition, study conception, design, data analysis and interpretation, manuscript writing and final manuscript review. Costa e Santos, Portes and Barbi contributed to data analysis and interpretation, results discussion and to final manuscript review. Sousa contributed to results discussion and to final manuscript review. Luiza contributed to funding acquisition, results discussion, manuscript writing and final manuscript review. All authors read and approved the final manuscript. 


\section{References}

1. Organização Pan-Americana da Saúde (OPAS). Servicios Farmacéuticos basados en la Atención Primaria de Salud. Washington: OPAS; 2013.

2. Organização Mundial de Saúde (OMS). El papel del farmacéutico en el Sistema de Atención de Salud. Tokyo: OMS; 1993.

3. Brasil. Resolução no 338, de 06 de Maio de 2004. Dispõe sobre a aprovação da Política Nacional de Assistência Farmacêutica. Diário Oficial da União 2004; 20 maio.

4. Brasil. Portaria no 3.916, de 30 de Outubro de 1998. Dispõe sobre a aprovação da Política Nacional de Medicamentos. Diário Oficial da União 1998; 10 nov.

5. Brasil. Ministério da Saúde (MS). Diretrizes para estruturação de farmácias no âmbito do Sistema Único de Saúde. Brasília: MS; 2009.

6. Brasil. Conselho Nacional de Secretários de Saúde (CONASS). Assistência Farmacêutica no SUS. Brasília; CONASS; 2007.

7. Brasil. Ministério da Saúde (MS). Assistência farmacêutica na atenção básica: instruções técnicas para sua organização. Brasília: MS; 2006.

8. Manzini F, Alencar LBO, Sales L, Bezerra MB, Campanha P, Macedo R, Mendes SJ, Contezini SNL, Santos SCM, Uehara WHO. O farmacêutico na assistência farmacêutica do SUS: diretrizes para ação. Brasília: Conselho Federal de Farmácia; 2015.

9. Mendes LV, Campos MR, Chaves GC, Silva RM, Freitas PS, Costa KS, Luiza VL. Disponibilidade de medicamentos nas unidades básicas de saúde e fatores relacionados: uma abordagem transversal. Saúde Debate 2014; 38(spe):109-123.

10. Karnikowski MGO, Nóbrega OT, Naves JOS, Silver LD. Access to essential drugs in 11 Brazilian cities: a community-based evaluation and action method. J Public Health Policy 2004; 25(3-4):288-298.

11. Emmerick ICM, Luiza VL, Pepe VLE. Pharmaceutical services evaluation in Brazil: broadening the results of a WHO methodology. Cien Saude Colet 2009; 14(4):1297-1306

12. Vieira FS. Possibilidades de contribuição do farmacêutico para a promoção da saúde. Cien Saude Colet 2007; 12(1):213-220.

13. Portela AS, Simões MOS, Fook SML, Montenegro Neto AN, Silva PCD. Prescrição médica: orientações adequadas para o uso de medicamentos? Cien Saude Colet 2010; 15(Supl. 3):3523-3528.

14. Oenning D, Oliveira BV, Blatt CR. Conhecimento dos pacientes sobre os medicamentos prescritos após consulta médica e dispensação. Cien Saude Colet 2011; 16(7):3277-3283.

15. Creswell JW, Clark VLP. Designing and Conducting Mixed Methods Research. 2a ed. Thousand Oaks: SAGE Publications Inc.; 2011.

16. Secretaria de Estado da Saúde de Minas Gerais (SES -MG). Adscrição e população dos municípios por macrorregiões e microrregiões de Saúde. Belo Horizonte: SES-MG; 2014. [acessado 2016 mar 30]. Disponível em: http://www.saude.mg.gov.br/images/anexos/PDR/ Adscricao_e_populacao_dos_municipios_por_macrorregioes_e_microrregioes_de_saude.pdf.

17. Patton MQ. Qualitative Research \& Evaluation Methods: Integrating Theory and Practice. $4^{\mathrm{a}} \mathrm{ed}$. Saint Paul: SAGE Publications Inc.; 2015.
18. Palinkas LA, Horwitz SM, Green CA, Wisdom JP, Duan $\mathrm{N}$, Hoagwood K. Purposeful sampling for qualitative data collection and analysis in mixed method implementation research. Adm Policy Ment Health 2015; 42(5):533-544.

19. Traverso ML, Salamano M, Botta C, Colautti M, Palchik V, Pérez B. Questionnaire to assess patient satisfaction with pharmaceutical care in Spanish language. Int J Qual Heal Care 2007; 19(4):217-224.

20. Larson LN, Rovers JP, MacKeigan LD. Patient satisfaction with pharmaceutical care: update of a validated instrument. J Am Pharm Assoc 2002; 42(1):44-50.

21. Gourley GK, Gourley DR, La Monica Rigolosi E, Reed P, Solomon DK, Washington E. Development and validation of the pharmaceutical care satisfaction questionnaire. Am J Manag Care 2001; 7(5):461-466.

22. MacKeigan LD, Larson LN. Development and validation of an instrument to measure patient satisfaction with pharmacy services. Med Care 1989; 27(5):522-536.

23. Ryan GW, Bernard HR. Techniques to Identify Themes. Field methods 2003; 15(1):85-109.

24. Starfield B. Primary Care: Balancing Health Needs, Services, and Technology. Don Mills: Oxford University Press; 1998.

25. Center for Pharmaceutical Management. Defining and Measuring Access to Essential Drugs, Vaccines, and Health Commodities: Report of the WHO-MSH Consultative Meeting, Ferney-Voltaire, France, December 1113, 2000. Arlington: Management Sciences for Health; 2003.

26. Sandelowski M, Voils CI, Knafl G. On Quantitizing. J Mix Methods Res 2009; 3(3):208-222.

27. Organização Mundial de Saúde (OMS). Essential medicines and health products. [acessado $2016 \mathrm{dez} 28$ ]. Disponível em: http://www.who.int/medicines/services/essmedicines_def/en/

28. Cassaro KOS, Heringer OA, Fronza M, Lenz D, Endringer DC, Andrade TU. Level of satisfaction of clients of public pharmacies dispensing high-cost drugs in Espírito Santo, Brazil. Brazilian J Pharm Sci 2016; 52(1):95-103.

29. Eilers GM. Improving patient satisfaction with waiting time. J Am Coll Heal 2004; 53(1):41-48.

30. Azeredo TB, Oliveira MA, Luiza VL, Esher A, Campos MR. User satisfaction with pharmacy services in the Brazilian National STD/AIDS Program: validity and reliability issues. Cad Saude Publica 2009; 25(7):15971609.

31. Luiza VL, Esher A, Azevedo TB, Avelar FG, Emmerick ICM, Oliveira MA. A dispensação de medicamentos para as pessoas vivendo com HIV: a experiência de um estudo avaliativo. In: Santos EM, Cruz MM, organizadores. Avaliação em saúde: dos modelos teóricos à prática da avaliação de programas de controle de processos endêmicos. Rio de Janeiro: Fiocruz; 2014. p. 129-160.

32. Bueno D, Machado A. Avaliação dos dispensários do distrito sanitário Glória-Cruzeiro-Cristal Porto Alegre -RS. Rev APS 2011; 14(1):4-11.

33. Souza LS, Porto JG, Lyra Júnior DP. Avaliação da estrutura e dos processos de organização e gestão da assistência farmacêutica em município do estado de Sergipe. Rev Ciências Farm Basica Apl 2011; 32(3):403-410. 
34. Grey E, Harris M, Rodham K, Weiss MC. Characteristics of good quality pharmaceutical services common to community pharmacies and dispensing general practices. Int J Pharm Pract 2016; 24(5):311-318.

35. Halsall D, Noyce PR, Ashcroft DM. Characterizing healthcare quality in the community pharmacy setting: insights from a focus group study. Res Social Adm Pharm 2012; 8(5):360-370.

36. Campbell SM, Roland MO, Buetow SA. Defining quality of care. Soc Sci Med 2000; 51(11):1611-1625.

37. Tribunal de Contas do Estado de Minas Gerais (TCE -MG). Relatório Final de Auditoria Operacional: Assistência Farmacêutica - Programa Farmácia de Minas. Belo Horizonte: TCE-MG; 2013. [acessado 2016 set 22]. Disponível em: https://www.tce.mg.gov.br/IMG/ Auditoria\%20Operacional/Farm\%C3\%A1 cia \%20 de\%20Minas\%20-\%20relat\%C3\%B3rio.pdf

38. Mendes ACG, Miranda GMD, Figueiredo KEG, Duarte PO, Furtado BMASM. Acessibilidade aos serviços básicos de saúde: um caminho ainda a percorrer. Cien Saude Colet 2012; 17(11):2903-2912.

39. Twigg MJ, Bhattacharya D, Clark A, Patel R, Rogers H, Whiteside H, Yaqoob M, Wright DJ. What do patients need to know? A study to assess patients' satisfaction with information about medicines. Int J Pharm Pract 2016; 24(4):229-236.

40. Arrais PSD, Barreto ML, Coelho HLL. Aspectos dos processos de prescrição e dispensação de medicamentos na percepção do paciente: estudo de base populacional em Fortaleza, Ceará, Brasil. Cad Saude Publica 2007; 23(4):927-937.

41. Ambiel ISS, Mastroianni PC. Outcomes of pharmaceutical care in Brazil: a literature review. Rev Cienc Farm Basica Apl 2014; 34(4):469-480.

42. Organização Mundial de Saúde (OMS). The World Medicines Situation 2011. 3a Edição. Geneva: OMS; 2011.

43. Pereira LRL, Freitas O. A evolução da Atenção Farmacêutica e a perspectiva para o Brasil. Rev Bras Cienc Farm 2008; 44(4):601-612.

44. Veber AP, Diehl E, Leite SN, Prospero ENS. Pharmaceutical assistance in local public health services in Santa Catarina (Brazil): characteristics of its organization. Braz J Pharm Sci 2011; 47(1):75-80.

45. Santa Helena ET, Andersen SE, Menoncin SM. Percepção dos usuários sobre acesso aos medicamentos na atenção primária. Cad Saude Colet 2015; 23(3):280288.

46. Gokcekus L, Toklu HZ, Demirdamar R, Gumusel B. Dispensing practice in the community pharmacies in the Turkish Republic of Northern Cyprus. Int J Clin Pharm 2012; 34(2):312-324.
47. Santos V, Nitrini SMOO. Indicadores do uso de medicamentos prescritos e de assistência ao paciente de serviços de saúde. Rev Saude Publica 2004; 38(6):819-834.

48. Toklu HZ, Akici A, Oktay S, Cali S, Sezen SF, Keyer-Uysal M. The pharmacy practice of community pharmacists in Turkey. Marmara Pharm J 2010; 14:5360.

49. Organização Mundial de Saúde (OMS). How to Investigate Drug Use in Health Facilities: Selected Drug Use Indicators. Geneva: OMS; 1993

50. Nkansah N, Mostovetsky O, Yu C, Chheng T, Beney J, Bond CM, Bero L. Effect of outpatient pharmacists' non-dispensing roles on patient outcomes and prescribing patterns. Cochrane Database of Syst Rev 2010; (7):CD000336.

51. Guerra Junior AA, Camuzi RC. Logística Farmacêutica. In: Osorio-de-Castro CGS, Luiza VL, Oliveira MA, Jaramillo NM, organizadores. Assistência Farmacêutica: gestão e prática para profissionais da saúde. Rio de Janeiro: Fiocruz; 2014. p. 469.

52. Jeffcott SA, Ibrahim JE, Cameron PA. Resilience in healthcare and clinical handover. Qual Saf Health Care 2009; 18(4):256-260.

53. Dekker S. Failure to adapt or adaptations that fail: contrasting models on procedures and safety. Appl Ergon 2003; 34(3):233-238.

54. Brasil. Ministério da Saúde (MS). Secretaria de Ciência, Tecnologia e Insumos Estratégicos (SCTIE). Serviços farmacêuticos na atenção básica à saúde. Brasília: SCTIE; 2014

55. Macinko J, Lima Costa MF. Access to, use of and satisfaction with health services among adults enrolled in Brazil's Family Health Strategy: evidence from the 2008 National Household Survey. Trop Med Int Heal 2012; $17(1): 36-42$.

Artigo apresentado em 26/10/2016

Aprovado em 03/02/2017

Versão final apresentada em 05/02/2017 